УДК 378. 016

DOI:

Олена Бабенко, кандидат філологічних наук, дочент кафедри романо-германських мов і перекладу Національного університету біоресурсів і природокористування України

\title{
ТЕОРЕТИЧНІ АСПЕКТИ ФОРМУВАННЯ КОГНІТИВНО-ІНТЕЛЕКТУАЛЬНИХ ЗДІБНОСТЕЙ СТУДЕНТІВ-ФІЛОЛОГІВ
}

У статті розглянуто проблематику формування когнітивно-інтелектуальних здібностей студентівфілологів. Проаналізовано та узагальнено основні підходи, форми когнітивного розвитку індивіда, особливості когнітивного проектування. Описано три форми когнітивного розвитку: культурно-історичну, навчально-діяльнісну та психолого-практичну. Мова є, в першу чергу, засобом спілкування, але вона є і знаряддям інтелекту. Будучи комунікативною діяльністю, спілкування, що засноване на розумінні та передачі думок $i$ переживань, передбачає акт мислення (когнітивної діяльності). У цььому сенсі цілісний та оптимально організований процес підготовки студентів-філологів має здійснюватися на основі когнітивно-діяльнісного niдходу.

Ключові слова: мислення; інтеріоризація; екстеріоризачія; когнітивний розвиток; академічні здібності студентів-філологів.

Табл. 1. Схема 1. Літ. 10.

Olena Babenko, Ph.D.(Philology), Associate Professor of the Romance and Germanic Languages and Translation Department, National University of Life and Environmental Sciences of Ukraine

\section{THEORETICALASPECTS OF FORMATION OF STUDENTS- PHILOLOGISTS' COGNITIVE-INTELLECTUALABILITIES}

The article highlights the trends of internationalization and labor mobility. This dynamics is especially evident in the sphere of professions related to intercultural communication and the use of foreign languages. The initial characteristic of modern education arises and focuses on the cognitive and personal development of the subject of the educational activity. Under these conditions, the role of interdisciplinary researches on the mechanisms of the personality's cognitive development is growing.

Language is, first of all, a means of communication, but it is also an instrument of intelligence. Communication is based on understanding and the thought and experience transfer. It provides the act of thinking (cognitive activity). In this sense, a holistic and optimally organized process of student-philologists' training should be carried out on the basis of a cognitive approach.

The main approaches, the forms of cognitive development of the individual, the features of cognitive projection are analyzed and generalized. Three forms of cognitive development are described, in particular, cultural-historical, active learning and psychological-practical. The cultural-historical form of cognitive development includes a genetic factor to be responsible for the development of natural mental functions, and social environment that forms the higher mental functions. The cultural-historical form is primary towards the other ones.

The active learning form includes such stages as learning, actions according to the model, a quasi-research (search-activity). The psychological and practical form of cognitive development is an activity for correction mistakes. It goes through three stages of development. The project of cognitive development is tightly connected with the principle of complementarity and connectivity of projection types.

In order to use the opportunities of projection activities for the development of philology students' thinking and their academic multidisciplinary skills, it is necessary to implement all mechanisms of cognitive development. skills.

Keywords: thinking; internalization; exteriorization; cognitive development; students-philologists ' academic

П остановка проблеми. Нині в усьому світі розробляються нові підходи до ааналізу, оцінки та управління якістю освіти. Як показують дослідження, набутий обсяг знань, умінь і навичок студентами у закладі вищої освіти ще не гарантує їхнього високого професійного рівня. Підготовка фахівця, здатного самостійно розвивати і керувати своїми особистісними ресурсами, ефективно вирішувати професійні завдання в умовах динамічно мінливих вимог до діяльності - вимога сучасних реалій.

Тенденції інтерналізації та мобільності робочої сили на порядок денний виносять питання, що стосуються визнання і впровадження в практику міжнародновизнаних кваліфікацій фахівців, що, в свою чергу, ставить нові завдання перед системою вищої освіти. 
Особливо ця динаміка простежується в професіях, пов'язаних 3 міжкультурною комунікацією і використанням іноземних мов.

Визначальною характеристикою сучасної освіти є їі орієнтація на когнітивний та особистісний розвиток суб'єкта навчальної діяльності. У цих умовах зростає роль міждисциплінарних досліджень механізмів когнітивного розвитку особистості.

Аналіз останніх досліджень і публікацій. Фундаментальний внесок у дослідження внутрішніх закономірностей когнітивного розвитку внесли чотири найбільш впливові в світовій психології школи: Вюрцбурзька, Л.С. Виготського, Дж. Брунера і Ж. Піаже.

Обгрунтуванню психологічних чинників компетентного педагогічного спілкування присвячені праці Л. Виготського, О. Бодалева, О. Леонтьєва, С. Рубінштейна, В. Рижова, Л. Петровської, І. Юсупова.

Аналіз професійної діяльності педагогалінгвіста і пов'язаних з нею здібностей, умінь і навичок проведено в дослідженнях О. Артем'єва, Є. Глєбова, Р. Мільруда.

Психологічні основи діяльності суб'єктів навчання описані в наукових працях Б. Ананьєва, А. Брушлинського, М. Волкової, І. Дерманової, Є. Ісаєва, О. Леонтьєва.

Мета статті - розглянути теоретичні аспекти формування когнітивно-інтелектуальних здібностей студентів-філологів.

Виклад основного матеріалу. Мова $\epsilon$, в першу чергу, основним засобом спілкування у людському суспільстві й такою ж мірою вважається знаряддям інтелекту. Будучи комунікативною діяльністю, спілкування, засноване на розумінні і передачі думок i переживань, передбачає акт мислення (когнітивної діяльності). У цьому сенсі цілісний і оптимально організований процес підготовки студента-філолога має здійснюватися на основі когнітивно-діяльнісного підходу.

Спектр проблем, що вивчаються когнітивною психологією, надзвичайно широкий. Він охоплює весь діапазон психічних процесів: відчуття, сприйняття, розпізнавання образів, увагу, навчання, пам'ять, формування понять, мислення, мову, емоції та процеси розвитку, а також і те, “як люди отримують інформацію про світ, як ця інформація може уявлятися людиною, як вона зберігається в пам'яті та перетворюється в знання та як ці знання впливають на нашу увагу і поведінку" [9].

Пізнавальні здібності в контексті теорій когнітивного розвитку є складним комплексним утворенням. "Пізнавальні здібності - властивості інтегральної індивідуальності ефективно реалізовувати функцію відображення та пізнання об'єктивно існуючого зовнішнього і внутрішнього світу за допомогою процесів відчуття, сприйняття, пам'яті, уваги, уяви, мислення й мови, психомоторики, які забезпечують високоефективну когнітивно-інтелектуальну та когнітивно-моторну діяльність" [7, 20].

Незважаючи на велику кількість теорій, що описують когнітивні процеси, усі вони грунтуються на двох основних підходах, які отримали назви емпіричного і наїтивістського.

Перша група теорій (Дж. Берклі, У. Джеймс, Г. Гельмгольц) зводиться до того, що становлення знань людини про світ залежить від дій над об'єктами (досвід детермінує розвиток), тоді як другий підхід (Платон, Р. Декарт, І. Кант) пов'язаний з ідеєю, що когнітивні процеси формуються і розвиваються не на основі дії та сприйняття, а за своїми власними законами.

В останні роки спостерігається зближення різних підходів до вивчення когнітивного розвитку. Всі дослідники розглядають когнітивний розвиток як активний, конструктивний процес, який має деякі біологічні передумови [8, 64]. Стисло характерні особливості та відмінні риси теорій когнітивного розвитку відображено в таблиці 1 .

Необхідно відзначити, що, незважаючи на наявність розбіжностей поглядів на природу психічних процесів, вчені дійшли спільного консенсусу про набуття низки якостей когнітивних процесів, а саме:

- володіння певними навичками;

- гнучкий підхід до вирішення завдань;

- висока швидкість обробки інформації;

- здатність планувати;

- здатність оперувати значним об'ємом інформації;

- володіння метакогнітивними знаннями;

- передбачливість і послідовність при вирішенні завдань;

- здатність концентрувати увагу і зусилля та ін. $[8,65]$.

Ми розглядаємо когнітивний розвиток як процес, що вирізняється ускладненням когнітивних структур і структурною спадкоємністю [1; 10].

В якості первинного чинника когнітивного розвитку слід розглядати культурне оточення індивіда. Культурне середовище, в яке індивід занурений 3 перших днів свого життя, надає непомітний, але потужний вплив на становлення його особистості, виступає провідною формою когнітивного розвитку.

Принциповим $є$ питання про механізми та 
Таблиця 1.

\begin{tabular}{|c|c|c|c|c|c|}
\hline Теорія & $\begin{array}{l}\text { Теорія } \\
\text { Ж. Піаже }\end{array}$ & $\begin{array}{l}\text { Концепція } \\
\text { Л.С. Виготського }\end{array}$ & $\begin{array}{l}\text { Теорія } \\
\text { діяльності } \\
\text { О. М. Леонтьєва }\end{array}$ & $\begin{array}{l}\text { Теорія } \\
\text { поетапного } \\
\text { формування } \\
\text { розумових дій } \\
\text { П.Я.Гальперіна. }\end{array}$ & $\begin{array}{l}\text { Теорія } \\
\text { В.В.Давидова }\end{array}$ \\
\hline $\begin{array}{l}\text { Характерні } \\
\text { особливості }\end{array}$ & $\begin{array}{l}\text { Вікова } \\
\text { детермінація } \\
\text { когнітивного } \\
\text { розвитку; } \\
\text { навчання } \\
\text { має } \\
\text { спиратися на } \\
\text { вже } \\
\text { досягнутий } \\
\text { рівень } \\
\text { розвитку. }\end{array}$ & $\begin{array}{l}\text { Жорстке } \\
\text { протиставлення } \\
\text { натуральних і } \\
\text { вищих психічних } \\
\text { функцій. } \\
\text { Розвиток } \\
\text { когнітивної сфери } \\
\text { йде від соціуму } \\
\text { до } \\
\text { індивіда. } \\
\text { Головна теза } \\
\text { концепції: } \\
\text { “навчання веде за } \\
\text { собою розвиток”. }\end{array}$ & $\begin{array}{l}\text { Всі психічні } \\
\text { процеси - це не } \\
\text { більше, ніж } \\
\text { інтеріоризована } \\
\text { зовнішня } \\
\text { діяльність } \\
\text { дитини під } \\
\text { керівництвом } \\
\text { дорослого }\end{array}$ & $\begin{array}{l}\text { Навчання } \\
\text { виступає прак- } \\
\text { тично єдиним } \\
\text { джерелом } \\
\text { когнітивних } \\
\text { процесів. } \\
\text { У процесі } \\
\text { навчання } \\
\text { необхідно } \\
\text { сформувати } \\
\text { орієнтовну } \\
\text { основу діі. }\end{array}$ & $\begin{array}{l}\text { Когнітивний } \\
\text { розвиток } \\
\text { Розгляда- } \\
\text { ється } \\
\text { як результат } \\
\text { розвиваю- } \\
\text { чого } \\
\text { навчання, } \\
\text { тобто як } \\
\text { штучний } \\
\text { процес. }\end{array}$ \\
\hline
\end{tabular}

засоби впливу культури на розумову сферу дитини.

Відповідь на це питання можна знайти в працях основоположника культурно-історичної психології Л. С. Виготського та його послідовників.

Один з них - американський психолог М. Коул вважає, що в культурне оточення дитини входять уречевлені пристосування, знаряддя поведінки, внесені в культуру попередніми поколіннями. Культурне середовище складається з безлічі артефактів - речей, створених людиною для людини. Артефакти, будучи уречевленою формою людської діяльності, є умовою і засобом когнітивного розвитку.

М. Коул розглядає артефакти як матеріальні й ідеальні продукти історії людства. Культура $є$ цілісною сукупністю артефактів, накопичених соціальною спільністю в ході їі історичного розвитку.

Аналізуючи природу артефактів, М. Коул посилається на дослідження свого співвітчизника - філософа-антрополога М. Вартовського, який виокремлює первинні, вторинні і третинні артефакти $[6,10]$.

До первинних артефактів відносяться ті знаряддя та засоби праці, які безпосередньо використовуються в побуті і на виробництві (наприклад, молотки, сокири, дубини, голки, чаші).

Вторинні артефакти є репрезентаціями первинних артефактів, а також способів дії при їхньому використанню. До цієї категорії артефактів відносяться стандартні способи досягнення цілей діяльності, різні види культурних схем та операціональних моделей. Вторинні артефакти є формою консервації та передачі культурно заданих способів дії. До них слід віднести, крім предметно-специфічних способів дії (наприклад, способи підрахунків), також логічні способи і прийоми (узагальнення, порівняння тощо) $[4,13]$.

Третинними $є$ артефакти, що становлять відносно автономний “світ”. Його утворюють правила, домовленості, продукти діяльності, які не мають своєї матеріалізованої форми. Ці артефакти існують у вільній грі людської уяви (віртуальний світ).

У когнітивістиці виокремлюють три форми когнітивного розвитку: культурно-історичну, навчально-діяльнісну і психолого-практичну.

Культурно-історична форма когнітивного розвитку включає генетичний чинник, який відповідає за розвиток натуральних психічних функцій, і соціальне середовище, яке формує вищі психічні функції.

Соціальне середовище включає етнокультурний чинник і освіту, яка задає більші параметри когнітивного розвитку: цінності, менталітет. Розуміння навчання (освіти) як усієї сукупності цілеспрямованих і стихійних впливів соціального середовища на розумовий розвиток дитини дозволяло Л. С. Виготському стверджувати, що навчання є формою психічного розвитку.

Культурно-історична форма є первинною по відношенню до двох інших.

Навчально-діяльнісна форма когнітивного розвитку сприяє перетворенню когнітивних етапів у когнітивні рівні, є засобом стабілізації когнітивного розвитку i оптимального функціонування новопосталих когнітивних 


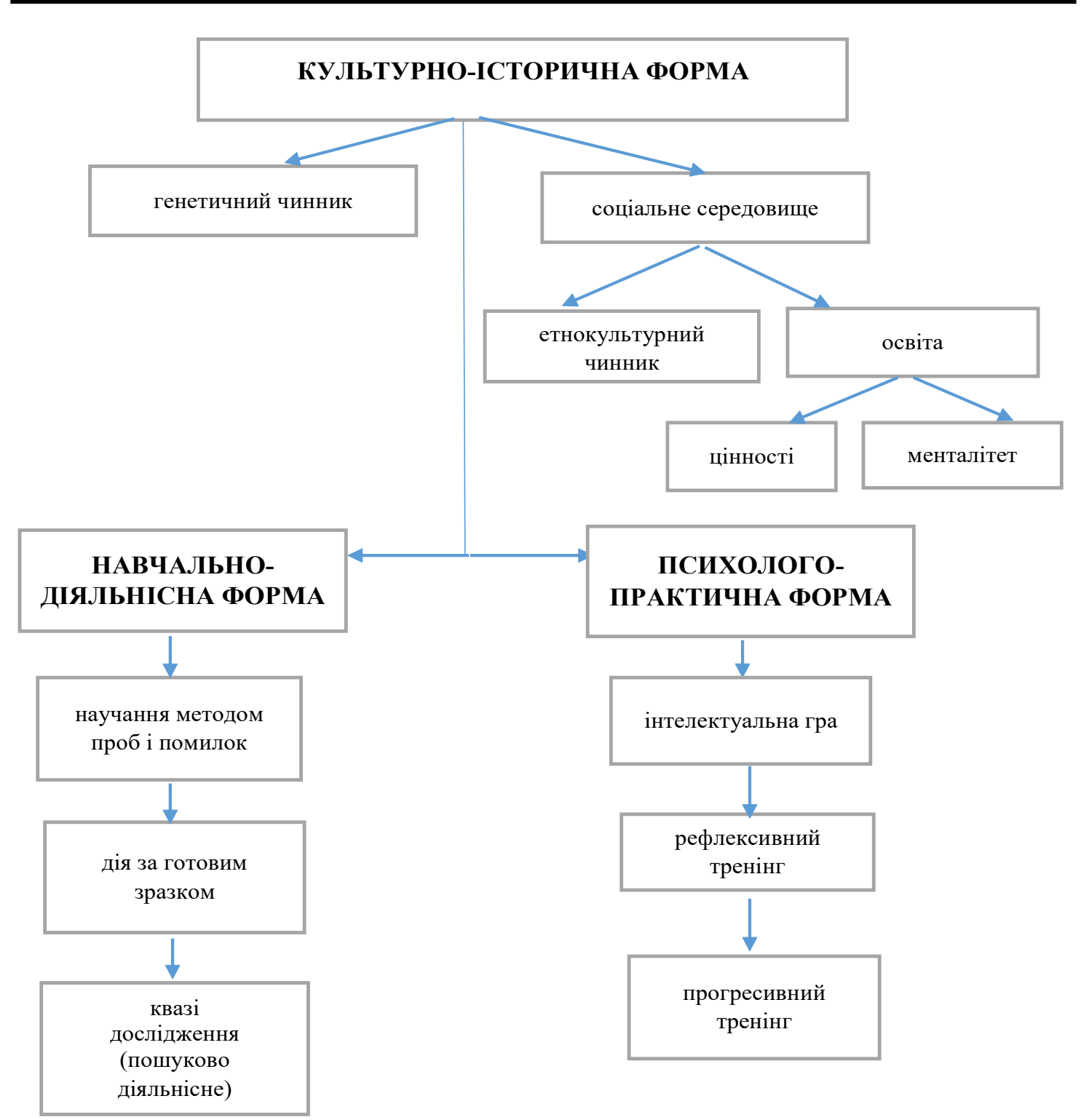

Схема 1. Форми когнітивного розвитку

структур. Розвиток навчально-діяльнісної форми включає такі етапи: научання, дії за зразком, квазідослідження (пошуково діяльнісне).

Научання відбувається в ході трудової і повсякденної діяльності та $€$ 1-им типом навчання за П.Я. Гальперіним. Воно грунтується на багаторазовому повторенні одних і тих же дій та є основою формування індивідуального досвіду і процесу передачі, розповсюдження та відтворення культури, є первинною навчальнодіяльнісною формою когнітивного розвитку i проекцією генотипу.

Другийетап(2-йтип навчання заП.Я. Гальперіним) розвитку цієї форми когнітивного розвитку - це дії за готовими зразками. Вони складають основу пояснювально-ілюстративного навчання.
Когнітивний розвиток тут здійснюється у формі засвоєння знань та оволодіння уміннями $\mathrm{i}$ навичками.

Третійетап(3-йтип навчання заП. Я. Гальперіним), або рівень, становлять квазідослідження, які формують основу розвиваючого навчання.

Вище проаналізовані форми когнітивного розвитку воєдино можна звести в схему (див. схему 1).

Навчання в педагогічному сенсі (як взаємодія діяльності вчителя й учнів) сприяє інтеріоризації (формуванню стійких внутрішніх психічних структур через зовнішню соціальну діяльність) [2, $188 ; 3,24]$. Сформовані когнітивні структури, типові для цього етапу когнітивного розвитку, трансформуються в нові структури, що 


\section{ТЕОРЕТИЧНІ АСПЕКТИФОРМУВАННЯ КОГНІТИВНО-ІНТЕЛЕКТУАЛЬНИХЗДІБНОСТЕЙ СТУДЕНТІВ-ФІЛОЛОГІВ}

конструюють наступний етап розвитку. При цьому трансформовані структури зберігаються, перетворюючись в рівні когнітивного розвитку. Відбувається акомодація наявних когнітивних схем, що становить головний механізм когнітивного розвитку (Ж. Піаже).

Сформовані когнітивні структури і когнітивні компетенції дозволяють засвоїти навчальний матеріал певного рівня складності. При цьому немає ніякої різниці, чи здійснюється це за допомогою дорослого (вчителя) або без нього. Інакше кажучи, відбувається екстеріоризація сформованих когнітивних структур, їхнє використання при асиміляції нового когнітивного досвіду. Асиміляція відображає актуальний рівень когнітивного розвитку, а акомодація - зону найближчого розвитку, або потенційний рівень когнітивного розвитку.

Психолого-практична форма когнітивного розвитку є діяльністю щодо усунення його недоліків. Вона проходить три етапи розвитку, трансформовані в рівні роботи за когнітивним розвитком (інтелектуальна гра, рефлексивний тренінг, прогресивний тренінг).

У сучасній психолого-педагогічній практиці тривимірна модель когнітивного макропроектування, яка розроблена В. С. Гончаровим, набирає популярності у межах впровадження в навчальний процес $[5,230]$. Вона включає три типи розвитку: соціокультурний, педагогічний, психотехнічний $[4,15]$.

Висновки. Отже, ми розглянули теоретичні аспекти формування когнітивно-інтелектуальних здібностей студентів-філологів. Основні підходи, форми когнітивного розвитку індивіда, особливості когнітивного проектування було проаналізовано та узагальнено.

Щоб скористатися наявними можливостями проектної діяльності для розвитку мислення студентів та їхніх академічних різнопланових здібностей, необхідна реалізація всіх механізмів когнітивного розвитку 3 метою формування у студентів-філологів ключових компетентностей, оволодіння якими вимагає значного інтелектуального розвитку: абстрактного і критичного мислення, саморефлексії та особистісного зростання.

\section{ЛІТЕРАТУРА}

1. Акопова М.А. Развитие когнитивных компонентов академических способностей студентов педагогических специальностей. Современные исследования социальных проблем (электронный научный журнал), Modern Research of Social Problems, №8(52), 2015

2. Бабенко O. B. Internalization of Ukrainian national values through the Taras Shevchenko museum in Toronto.
Феномен Тараса Шевченка: лінгвістичний і історічний і соціофілософський аспекти (до 205-річчя від дня народження): зб. матеріалів міжнародної наук.-практ. конф., Київ 12-13 березня 2019 р. Київ, С. 188-189.

3. Бабенко О. В. Генезис поняття “інтеріоризація” в психолого-педагогічній науці. Актуальні проблеми педагогіки, психології та професійної освіти, 2018. 2 (1). C. 23-28.

4. Гончаров В.С. Соотношение форм когнитивного развития и типов его проектирования // Психологическая наука и образование. 2004. № 2. C. 11-19.

5. Гончаров В.С. Психология проектирования когнитивного развития: монография. Курган: Издательство Курганского государственного университета, $2005.235 \mathrm{c}$.

6. Коул М. Культурные механизмы развития. Вопросы психологии, 1995, № 3. С.5-20.

7. Озеров, В.П., Соловьева, О.В. Диагностика и формирование познавательных способностей учащихся: учеб. пособие. Ставрополь, 1999. 112 с.

8. Романова М.А. Развитие познавательных способностей в контексте когнитивной психологии. Психология №2 (55), 2008. С. $63-70$.

9. Солсо Р.Л. Когнитивная психология. Москва, $2002.600 \mathrm{c}$.

10. Чайка В., Петрова Н. Інтелектуальна культура вчителя як фактор інновацій у педагогічній діяльності: монографія. Тернопіль, 2014. 308 с.

\section{REFERENCES}

1. Akopova, M. A. (2015). Razvitiye kognitivnykh komponentov akademicheskikh sposobnostey studentov pedagogicheskikh spetsialnostey [Development of cognitive components of academic abilities of students of pedagogical spesialites]. Modern Research of Social Problems, No.8 (52), pp.268-275. [in Russian].

2. Babenko, O. V. (2019). Internalization of Ukrainian national values through the Taras Shevchenko museum in Toronto. Fenomen Tarasa Shevchenka: linhvistychnyi $\mathrm{i}$ istorichnyi i sotsiofilosofskyi aspekty (do 205-richchia vid dnia narodzhennia): zb. materialiv mizhnarodnoi nauk.prakt. konf. - The Phenomenon of Taras Shevchenko: the linguistic and historical and socio-philosophical aspects (to the 205th Birthday): Collection of Proceedings of the International Scientific and Practical Confernce. Kyiv, 1213 March 2019 r. pp. 188-189. [in Ukrainian].

3. Babenko, O. V. (2018). Henezys poniattia "interioryzatsiia" v psykholoho-pedahohichnii nautsi [Genesis of the concept of "internalizations" in psychological and pedagogical science]. Current problems of pedagogy, psychology and professional education. Vol.2 (1), pp.23-28. [in Ukrainian].

4. Goncharov, V. S. (2004). Sootnosheniye form kognitivnogo razvitiya i tipov ego proyektirovaniya [Correlation of forms of cognitive development and types of its projection]. Psychological sciences and education, No. 2, pp. 11-19. [in Russian].

5. Goncharov, V. S. (2005). Psikhologiya proyektirovaniya kognitivnogo razvitiya: monografiya. [Projection 
Psychology of Cognitive Development: Monograph. Kurgan:]. Kurgan: Publishing House of Kurgan State University, 235 p. [in Russian].

6. Koul, M.(1995). Kulturnyye mekhanizmy razvitiya [Cultural mechanisms of development]. Psychology issues, No. 3, pp.5-20. [in Russian].

7. Ozerov, V. P. \& Soloveva, O. V. (1999). Diagnostika $i$ formirovaniye poznavatelnykh sposobnostey uchashchikhsya: ucheb. Posobiye [Diagnostics and the formation of students' cognitive abilities of students: textbook]. Stavropol, 112 p. [in Russian].
8. Romanova, M. A. (2008). Razvitiye poznavatelnykh sposobnostey $\mathrm{v}$ kontekste kognitivnoy psikhologii [The development of cognitive abilities in the context of cognitive psychology]. Psihology №2 (55), pp. 63 -70. [in Russian].

9. Solso, R. L. (2002). Kognitivnaya psikhologiya [Cognitive psychology]. Moscow,600 p. [in Russian].

10. Chaika, V. \& Petrova, N. (2014). Intelektualna kultura vchytelia yak faktor innovatsii u pedahohichnii diialnosti: monohrafiia [The intellectual culture of a teacher as a factor in innovation in pedagogical activity: a monograph]. Ternopil, 308 p. [in Ukrainian].

Стаття надійшла до редакції 27.08.2019

УДК 373.3.015.31:172.15

DOI:

Наталія Калита, кандидат педагогічних наук, доиент кафедри педагогіки та методики початкової освіти Дрогобииького державного педагогічного університету імені Івана Франка

\section{ФОРМУВАННЯ ОСНОВ НАЦІОНАЛЬНО-ПАТРІОТИЧНОГО ВИХОВАННЯ В УЧНІВ ПОЧАТКОВОЇ ШКОЛИ}

У статті проаналізовано поняття національно-патріотичного виховання, визначено основні його складові; розкрито формування основ національно-патріотичного виховання учнів початкової иколи; розглянуто основні завдання які висвітлені у Концепиї̈ начіонально-патріотичного виховання дітей та молоді та можливості їх впровадження в освітній прочес початкової школи; розглянуто патріотичне виховання як основу національнопатріотичного виховання, та розкрито основні принципи через які воно реалізується в практиці.

Ключові слова: національно-патріотичне виховання; концепція національно-патріотичного виховання; учень; виховання; вчитель початкової иколи.

Лim. 11.

Nataliya Kalyta, Ph.D.(Pedagogy), Associate Professor of the Pedagogy and Methodology of Primary Education Department Drohobych Ivan Franko State Pedagogical University

\section{THE FORMATION OF BASES OF NATIONAL PATRIOTIC EDUCATION OF PRIMARY SCHOOL PUPILS}

Today Ukraine and its citizens are becoming direct participants in the processes that are extremely important for the further determination, first of all, of their fate and the history of their neighbours. A modern person must have a certain amount of knowledge in order to fulfil themselves, to determine their place in society. This period of development of society radically changes the requirements for the level of upbringing of the individual. Today, the formation of a citizen, a patriot, a spiritually developed and morally mature person who is ready to withstand the challenges of life is becoming especially important.

In the article, we focus on the main tasks highlighted in the Concept of national patriotic education of children and youth (2015). We single out the principles defined in the Concept, which contribute to a better development by students of the fundamentals of national patriotic education, the education of a Ukrainian patriot who can identify national dignity, fulfill the duties inherent in a certain age, and be the Ukrainian national culturebearer. In the national patriotic education of students, the role of the teacher besides the family is extremely important, therefore we argue that the teacher is a key figure in education, and his level of professional training is a priority component of school success, the effectiveness of the use of new information technologies and teaching aids. It is teachers who are responsible to convey to students the basic concepts of national patriotic education. Children are ready to perceive information regarding their family, relatives, customs and traditions of the Ukrainian state. Since the primary school lays the foundation for national patriotic education, the formation of their love for their native land, for their belonging to a certain family, relatives, in this regard $K$. Ushynskiy noted that children should learn their native language, geography and history.

Keywords: national patriotic education; a concept of national patriotic education; pupil; an education; a primary school teacher.

П

остановка проблеми. Зміни, що відбуваються в нашій державі, у іï економічній, політичній і соціальній сферах, зумовлюють потребу перетворення й оновлення системи освіти й зокрема педагогічної освіти. Національна Доктрина розвитку освіти 